\title{
The effect of new business creation on employment growth in regions facing population decline
}

\author{
Heike Delfmann ${ }^{1} \cdot$ Sierdjan Koster $^{1}$
}

Received: 15 October 2014 / Accepted: 30 October 2015 / Published online: 11 January 2016

(C) The Author(s) 2016. This article is published with open access at Springerlink.com

\begin{abstract}
Particularly in declining regions, new businesses creation is seen as a means to secure (future) employment opportunities. However, the way in which new business creation exerts its influence on employment is not evident. Do start-ups in these areas influencing employment change as they do in growth regions? We disentangle the long- and short-term employment effect of new business creation in municipalities in the Netherlands between 1996 and 2010. We conclude that the regional context matters a great deal for the local employment effect of business creation. Further, it is shown in contexts with modest population decline, new businesses are still an important generator of employment opportunities.
\end{abstract}

JEL Classification $\mathrm{M} 13 \cdot \mathrm{L} 26 \cdot \mathrm{O} 18 \cdot \mathrm{R} 11 \cdot \mathrm{J} 23$

\section{Introduction}

After centuries of continuous population growth, many regions in Europe are currently experiencing a period of stagnation or depopulation (Haartsen and Venhorst 2010; Reher 2007). Historically, population growth has always been considered a sign of a successful society and a successful economy (Reher 2007; Glaeser et al. 1992, 1995),

Electronic supplementary material The online version of this article (doi:10.1007/s00168-015-0738-1) contains supplementary material, which is available to authorized users.

Sierdjan Koster

sierdjan.koster@rug.nl

Heike Delfmann

h.s.delfmann@rug.nl

1 Department of Economic Geography, Faculty of Spatial Sciences, University of Groningen, Landleven 1, 9747 AD Groningen, The Netherlands 
implicitly stating that population decline is a sign of being unsuccessful. Moreover, classical economic theory explicitly predicts that a larger population, by allowing for economies of scale and labour division, improves productivity, and vice versa (Coleman and Rowthorn 2011). A decline in population would thus mean slower output growth, ceteris paribus, as well as other negative consequences of depopulation, such as the restructuring of population composition causing labour shortages through ageing.

Given the likely declining labour supply, population decline is strongly associated with economic decline, although this association is not automatic or inevitable (Gáková and Dijkstra 2010). In the Netherlands, for example, the Parkstad Limburg region simultaneously experiences population decline and a growing employment rate (Limburg 2011). Population decline and ageing are noticeable trends in many Dutch regions. Although decline in the Netherlands has not yet taken dramatic proportions as it has elsewhere in Europe (Barca 2009; European Commission 2010), the change is structural and incremental and there is a challenge in keeping the declining regions viable in the future (SER 2011). Particularly for declining regions, new business creation is seen as a means to secure current and future employment opportunities (Andersson and Noseleit 2011; Armington and Acs 2002; Audretsch and Thurik 2000; Stam 2010; Wennekers and Thurik 1999). Yet, the mechanisms underlying regional employment dynamics governed by new business creation, especially in the context of population decline, remain unclear, hindering the formulation of effective regional development policies.

There is a clear association between population decline and new business creation. Firstly, the number of start-ups is likely to decline as the number of potential entrepreneurs declines. This is strengthened by the effects of ageing as the probability of a person starting their own firm takes the shape of an inverted $U$ and thus decreases after a certain age (Bönte et al. 2009; Schneider and Eichler 2007). In addition, regions with a declining population have to deal with a decreasing labour and consumer market. Despite these processes impeding new business creation, the start-up rate of new firms does not necessarily drop (Delfmann et al. 2014). Secondly, the employment effects of new business creation may be mediated by population decline. Although the exact role of the regional economic context on the effects of business creation is not fully understood, empirical evidence does reveal notable inconsistencies regarding the economic impact of the firms started in different types of regions (Audretsch and Fritsch 2002; Carree and Thurik 2003; Eliasson and Westlund 2013; Fritsch 2008; Li et al. 2011; Koster 2011; Willis et al. 2012). The spatially differing employment effects of business dynamics can be attributed to the types of business that are started in specific regions and the nurturing effect of the regional economic context, including population dynamics. This paper contributes to the understanding of the mechanisms underlying regional differences in employment change through assessing the employment effects of new business creation in the context of population change.

The remainder of this paper is structured as follows. We first discuss the theoretical links between entrepreneurship and regional employment and the ways in which the regional context may influence this relationship. Important distinctions are made between direct and indirect effects on employment in the theoretical section. Then we outline the model structure and the data employed. Following a presentation of the 
results, we discuss specific insights arising from the analysis, and finally we provide some brief conclusions.

\section{Theoretical framework}

We expect a positive relation between new business creation and local job growth as there are many ways in which entrepreneurs facilitate economic growth, for example through job creation and innovation which in turn increase productivity and competition (Acs and Audretsch 1990, 2003; Carree and Thurik 2003, 2008; Glaeser et al. 1992). The relationship between new business creation and economic development is, however, complex and varies over time. New businesses have a direct effect due to the jobs created in the new firms and an indirect effect influencing employment in firms in the region, which can be both positive and negative.

\subsection{Impact over time}

There is consensus on the overall pattern in the relationship between start-ups and employment change over time. Fritsch and Mueller (2004) made an important contribution showing that the impact of start-ups on employment growth follows an s-shape wave pattern. As Fig. 1 shows, the impact of new firms on employment growth is not stable over time, with immediate positive effects being followed by short-term negative effects and again by long-term positive effects. Both positive and negative impacts on employment growth are therefore likely to occur, depending on the time lag of the start-up cohort and a number of studies have confirmed this short-, mediumand long-term pattern (Storey 1994; Fritsch and Noseleit 2009, 2013a, b; Andersson and Noseleit 2011; Koster 2011; Li et al. 2011).

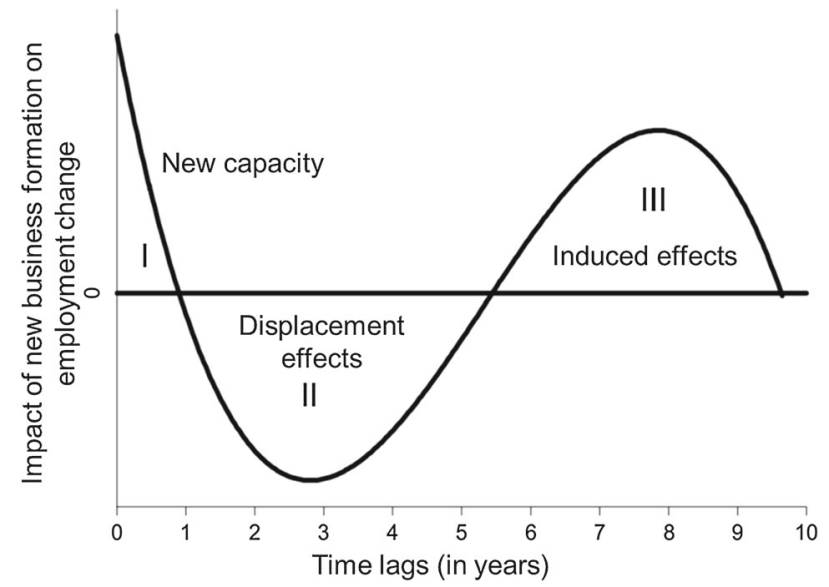

Fig. 1 New business creation has both positive and negative impacts on employment change throughout time. Source: Fritsch (2008) 
When new businesses enter a market, they may have both direct and indirect effects on employment development (Fritsch and Mueller 2004). The direct effect refers to the new jobs that are created internally, most noticeable immediately after start-up and indicated as stage 1 in Fig. 1. This direct effect includes the job created for the entrepreneur and for possible new employees immediately at the start or during the following years. It is therefore by definition positive in the first year. However, in many cases the entrepreneur's 'job' will be a substitute for his or her previous job in employment and most new firms do not start out by hiring many, if any, new employees. Some new businesses grow where other fail or remain stable. The growing start-ups quickly cancel out against declining or discontinuing start-ups in the same the cohort. The positive direct effect is thus likely to be short term.

The medium- and long-term employment dynamics are mostly due to the indirect effects. A start-up will not initially affect incumbent firms, but allowing for some response time there is a stage of exiting capacities resulting from the exit and decline of incumbents (Baptista et al. 2005). The indirect employment effect entails the response of incumbent firms to the entry of new firms. The impact of start-ups on regional employment change depends critically on the consequences for the incumbent firms. New firms are generally smaller than the average incumbent firm (Van Stel and Storey 2004), if a start-up forces incumbents to exit the market it causes negative employment growth. This indirect result from the new firms is referred to as the displacement effect, depicted as stage 2 in the figure. The stronger the start-ups, the bigger the displacement effect will be. Stage 2 negatively influences employment, not only due to the indirect displacement effect but also direct due to the failure of new firms (Baptista et al. 2005; Fritsch and Mueller 2004; Carree and Thurik 2008).

The third and final stage revolves around the indirect effects and is referred to as the induced effect or supply side effects. It reflects the improved competitiveness due to increased competition and the crowding out of the weakest incumbents, which thereby strengthens the innovation and productivity capabilities of the market. These supply side effects should result in a positive impact on employment (Fritsch and Mueller 2004; Koster and Stel 2014; Li et al. 2011; Van Stel and Suddle 2008). Fritsch (2008) argues that the induced employment effects of start-ups are crucial as they describe the long-term effects on the supply side. Based on the less favourable conditions, less competition and varying motivations for start-ups, we hypothesize that declining regions are less likely to see strong positive effects from entrepreneurship, particularly in the long term, and the reasoning for this is set out below.

\subsubsection{Regional differences in impact}

There is evidence that the employment effects of start-ups differ across regional contexts: some places enjoy above-average job effects from start-ups (Fritsch and Noseleit 2013a, b). Although it is still not fully understood what governs the regional differences in the impact of start-ups, there are two likely mechanisms. The first is spatial sorting in the types of businesses started. In this respect, Koster and Stel (2014) and Mueller et al. (2008) argue that the longer-term positive impact afforded by the process of creative destruction will only occur when the quality of the new firms is high enough. The second mechanism is the business context in which the start-ups are active. Growth 
of the start-ups and their influence on other businesses may be impacted by market conditions, the presence of competitors and potential spill-over effects from other businesses. The empirical results in Fritsch and Noseleit (2013a,b) show that cities enjoy above average job creation from start-ups which is in line with the argument that agglomeration benefits positively influence the employment effects of start-ups. In the following, we will discuss how changing demographics, with a focus on population decline, can influence both mechanisms.

Many arguments suggest that a context of population decline is likely to generate lower quality start-ups. First, regions experiencing population decline usually see their young people migrating out while simultaneously experiencing a declining workforce. In particular, the higher educated are likely to find employment elsewhere. As the quality of start-ups depends on the level of human capital or ability (Skuras et al. 2005; Davidsson 1991) — often operationalised by the level of education of the owner and employees - the higher educated the entrepreneur and employees are, the higher the growth potential of the new firm. As the share of highly educated entrepreneurs is likely declining as a result of selective migration, the employment impact of start-ups is likely lower (Mueller et al. 2008; Van Stel and Suddle 2008). Second, the entrepreneur's age is relevant for growth potential, with younger entrepreneurs being more dynamic and more risk taking (Meccheri and Pelloni 2006). The average age is higher in declining regions, as decline and ageing go hand in hand (OECD 2011). The third aspect negatively influencing the overall quality of new businesses in declining regions is the entrepreneurs' initial motivation (Acs and Varga 2005; Gilad and Levine 1986; Shane 2009). Acs and Varga (2005) showed that necessity driven entrepreneurship has no effect on employment growth, while opportunity-driven entrepreneurship has a positive and significant effect. Similar results have been found by others (Sternberg and Bergman 2003; Reynolds et al. 2002). In an adverse regional context, it is likely that we find less job diversity, fewer jobs in general, lower education levels and lower wages than in growing and prosperous regions, and this also possibly results in a stronger push effect regarding entrepreneurship (Carrasco 1999). Entrepreneurs in declining regions could be relatively more motivated by necessity, as employment opportunities are limited and people have little to lose in starting their own business (Brooksbank et al. 2008; OECD 2004; Williams and Williams 2012). In addition, population decline is often accompanied by uncertainty as it possibly affects the level of support both financially and socially (Little and Triest 2001; Fésüs et al. 2008), which can amplify negative effects, as perceived risks might be higher, potentially causing new start-ups to lower their ambitions.

The changing demographics in regions facing population decline likely have an impact on the motivations and abilities of the entrepreneurs and consequently, the characteristics of the start-ups are influenced. In terms of the framework discussed in the above (Fig. 1), the changing characteristics of the start-ups can reduce both the direct and indirect employment effects. Changing ability and motivations of the entrepreneurs may cause relatively low growth potential as well as lower growth aspirations, which translates in a low-relative to growing regions - direct employment effect. The reduced competitiveness of the start-ups can also lower the indirect employment effect as incumbent firms are less likely to be challenged by the newcomers. In other words, the start-ups do not spur a creative destructive process. This is in correspondence with 
the results in Koster (2011), who finds that particularly the indirect employment effect is mediated by the type of start-up.

The regional context itself can also explain regional differences in the employment effects emanating from start-ups. It provides start-ups, or firms in general, with the necessary resources for growth. Particularly access to labour and consumer markets are key factors for continuity and growth of start-ups (Shearmur and Polèse 2007). As many start-ups are in non-tradable consumer-based services and retail, access to local consumer markets is crucial. With a declining population, the local market size is inevitably shrinking too. Reilly's law of retail gravitation (Reilly 1931) suggests that the decline of the market size may even be more than proportional to the population decline. His law explains how stores located in centres with greater populations draw customers from farther distances than those in smaller centres (Chasco and Vicéns 1998), for example because consumers are likely to combine shopping trips in the larger centres. Mimicking Newton's law of gravitation, Reilly's law states that interaction is governed by a mass variable (population) which exerts positive attraction and a friction variable (distance) which discourages interaction (Chasco and Vicéns 1998). The breaking point is the location at which the relative attractiveness for consumers, given the distance to either centre, is equal: consumers are indifferent about going to either location for their shopping (Alhabeeb 2014). If population declines in one locality, the breaking point shifts towards the bigger centre more than proportionally, all else equal. Over and beyond the decline in the size of the own local market, the centre facing population decline is thus likely to lose additional market share to the nearest bigger centre. An argument to the same effect is made in New Economic Geography models in which the spatial distribution of demand is a key determinant of economic outcomes. It is argued that higher demand gives rise to a more than proportionate increase in production, a result known as the home market effect (Head and Mayer 2006).

Hoogstra and Dijk (2004) focus on the access to labour markets in determining employment growth of firms. Using an econometric model based on a data set of circa 35,000 establishments in the three northern provinces of the Netherlands, they find that 'location matters'. Even on the relatively limited spatial scale studied, access to labour was found to affect employment growth. With the number of potential employees decreasing, so do the opportunities for firm growth. On the flip side, low rents were also associated with employment growth and rent is typically lower in declining regions.

Given the declining resources for growth available, both in terms of demand and supply, it can be expected that the long-term direct employment growth in start-ups in regions facing population decline is relatively modest (phase 2 and 3 in Fig. 1). As a result, in regions with population decline, the immediate direct effect (phase 1) may be relatively important in the total direct employment effect. The expected role of a context typified by population decline on the indirect employment effect of start-ups are speculative given that both incumbents and start-ups alike have to deal a declining stock of resources for growth. If, however, incumbents are better equipped to harness the resources that have remained available, it would imply that the indirect effect of start-ups on employment effects in incumbent firms will be lower than in regions where resources for growth are abundant. 


\subsection{Expectations}

Combining the arguments pertaining to the types of start-up and the regional context in which they are started, we expect that in declining regions most of the positive effects of new business creation are visible in the first and second year of the start-up cohorts: there is less growth potential as the consumer base is declining and quality of the firm is expected to be lower. In this type of regions, we should therefore observe a relatively high immediate effect (stage 1 of Fig. 1), compared to low long-term effects on employment growth. The direct effect will be similar to other regions but the 'Schumpeter-effect' of crowding out and increased competition (stages 2 and 3 of Fig. 1) is expected to be lower, resulting in a different pattern. The following hypothesis is formulated based on this assumption: (1) the pattern of the impact of new business creation in declining regions will be different; new business creation will have most impact on employment in the first, immediate stage after start-up and relatively modest effects in stage 2 and 3. Growing regions should benefit in the long run from better quality firms, more competition and market potential. They should show a stronger displacement effect and higher supply side effects, which should result in higher total employment growth. The hypothesis resulting from this is as follows: (2) the total impact of new business creation on subsequent total employment change will be lower in declining regions.

\section{Data and methodology}

\subsection{Data}

We use the LISA register database (Landelijk Informatiesysteem van Arbeidsplaatsen en vestigingen) to determine the impact of start-up cohorts on employment change. The LISA database holds employment information on all establishments with paid jobs in the Netherlands, and it is updated on a yearly basis. The longitudinal nature of the data and the fact that it is a register of all establishments in the Netherlands, allows us to identify new establishments. We use the dataset for the period 1996-2010. Individual establishments were identified firstly by firm name and address. A startup is identified if the combination of both the address and the firm name was new within the region on a NUTS 3 level. ${ }^{1}$ In addition, we only included start-ups with a maximum of 15 employees in order to exclude new establishments of larger firms with multiple establishments. The dataset consists of over 12 million cases between 1996 and 2010. The data is truncated, due to which information on start-ups in 1996 is unavailable. There is a data limitation concerning the collection. LISA collects the data via 20 agencies, which use slightly different procedures. This leads to a certain degree of systematic bias in the data. In order to mitigate a possible impact of this data

\footnotetext{
1 The NUTS 3 level was chosen as most firm relocations are local (Van Dijk and Pellenbarg 2000) and the risks of false identifications due to firms holding the same name on a NUTS 2 level was considered too great.
} 
bias, we include a control variable for the agencies in all regressions. Additional data on population change and controls were retrieved from Statistic Netherlands (CBS).

Our spatial unit of analysis is the municipality, a low level of aggregation. The analyses are performed with all municipalities in the Netherlands, aggregated to the number of municipalities in 2011 (418) to facilitate comparisons between several years. The municipal level is preferred for two reasons. First, as new business creation is often a local phenomenon (Dahl and Sorenson 2012; Sternberg 2011), new businesses are likely to be located in the home region primarily serving local and regional markets and are therefore heavily influenced by local conditions (Bosma et al. 2008; Stam 2009). Compared to other countries, the commuting patterns of workers in the Netherlands are relatively short (OECD 2013), and municipalities do indeed play an important role in shaping labour markets, housing and unemployment policies (Knoben et al. 2011). Second, a small spatial scale allows us to identify the declining regions and to understand specific local issues in the Netherlands (OECD 2008). Growth and decline occur side by side and when using larger regions, such as NUTS 3, only a few regions can be identified as declining over a longer time period. Figure 2 provides a visualization of population change on the municipal level. Yet, population decline does not stop at the municipal border, and labour markets also often have a larger spatial scale than the municipal scale. We therefore include some controls to cope with these issues, as explained below.

\subsection{Dual causality}

Although local economic performance is to a great extent determined by the local entrepreneurial potential and physical preconditions (Baumgartner et al. 2013), the relationship between business creation and employment change is likely a two-way relationship: these factors influence each other. A strong economic performance by a region could increase that region's start-up rate since it implies a higher level of entrepreneurial opportunities. Most empirical research pays attention to one particular direction (Hartog et al. 2010). For the purpose of this study, we are mainly concerned with the impact of start-up rates on employment change. However, given that the opposite relationship can be expected to hold as well, a one directional analysis could lead to biased results, overestimating the effect of start-ups if not estimated simultaneously (Fritsch 2015). A number of studies have attempted to disentangle this relationship, most extensively that by Hartog et al. (2010) who provide an overview of studies examining this issue and they only find a weak effect of growth in previous periods on the level of new business formation. Also Fritsch (2015) concludes that the causality runs primarily from business creation to employment growth rather than the other way around. Still, we performed a Granger causality test to verify the direction of causality. The test does not suggest any impact from reversed causality and the risks of overestimating the results are very limited. Given the limited impact of reversed causality we prefer the Almon lag method, explained below, as it allows us to distinguish the direct and indirect effects over time. The test results are included in Table A1 of the ESM Appendix. 


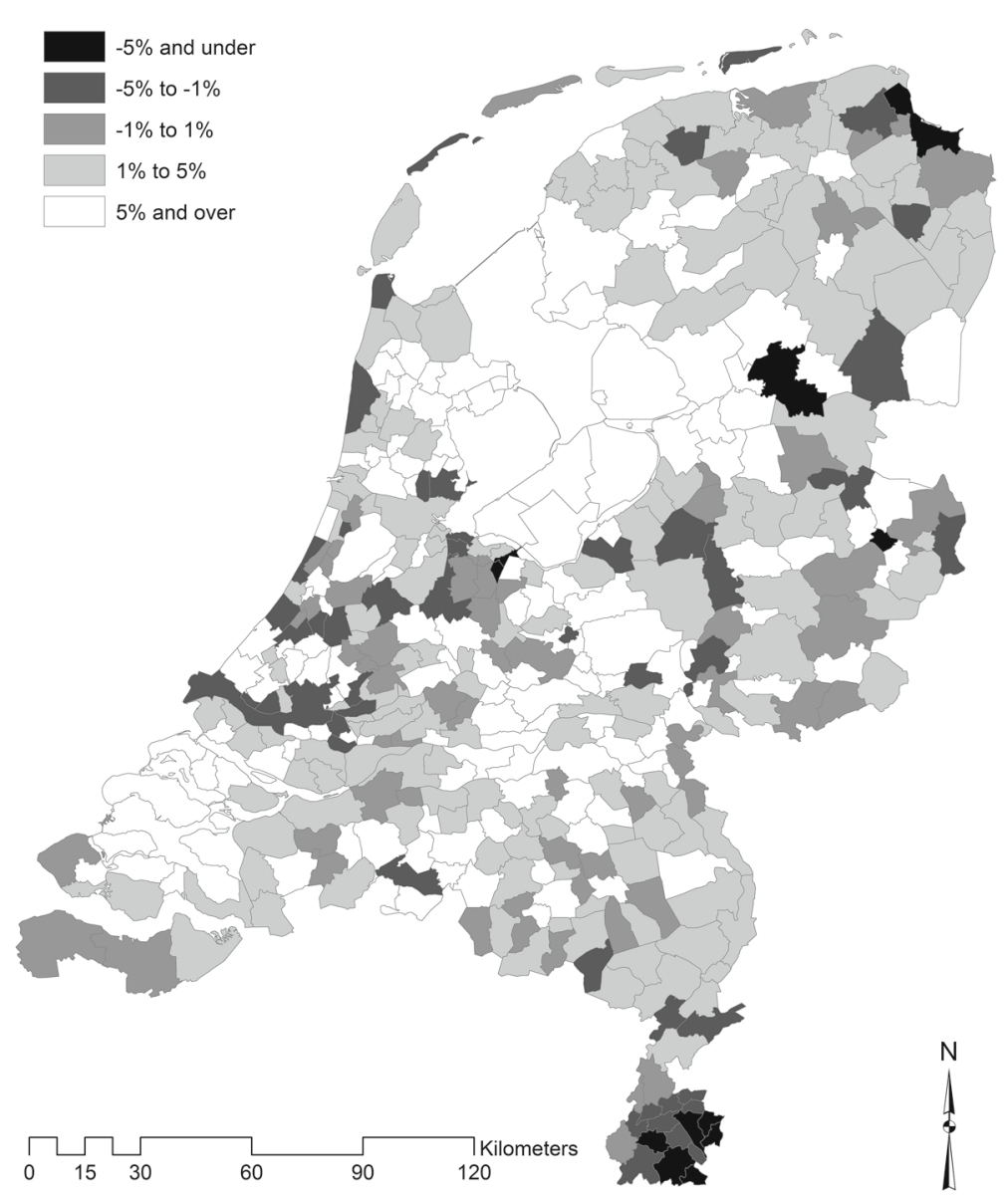

Fig. 2 Map of the Netherlands: population change 1997-2007

\subsection{Model}

As explained earlier, various studies of the relationship between new business creation and employment growth have shown diverse results, possibly because of the variety of empirical approaches used (Baptista et al. 2005). Using a similar method will help to make the outcome more comparable to previous results. We therefore follow the method by Fritsch and others (Fritsch et al. 2008; Fritsch and Noseleit 2009, 2013b). The regressions are run with three different dependent variables: total employment change, employment change in new firms and employment change in incumbent firms. The latter two help to disentangle the effects of new business creation, to determine whether the start-ups exert the most influence in the relative short term, or whether the biggest impact on employment is seen in firms that have been in the region for a decade or longer (Fritsch and Noseleit 2013b).

The first dependent variable in our model is defined as the annual employment change $\left(\triangle \mathrm{EMP}_{\text {total }}\right)$ in a municipality in the period 1997-2010. Total employment 
change is thus simply percentage change, calculated by total employment in time $t$ compared to the total employment in the year before, time $t-1$.

$$
\Delta \mathrm{EMP}_{\text {total }}=\left(\mathrm{EMP}_{\text {total } t=0}-\mathrm{EMP}_{\text {total } t-1}\right) / \mathrm{EMP}_{\text {total } t-1}
$$

The effect on employment change in new firms is calculated per cohort $\left(\mathrm{EMP}_{\text {new }}\right)$. Jobs created by new firms are calculated by summing up the employment in the startups in the preceding 9 years. $^{2}$

$$
\begin{aligned}
& \mathrm{EMP}_{\text {new } t=0}=\mathrm{EMP}_{\text {cohort } t=0} \text { to } \mathrm{EMP}_{\text {cohort } t-9} \text { in year } t=0 \\
& \mathrm{EMP}_{\text {new } t-1}=\mathrm{EMP}_{\text {cohort } t-1} \text { to } \mathrm{EMP}_{\text {cohort } t-9} \text { in year } t-1
\end{aligned}
$$

The employment in incumbent firms $\left(\mathrm{EMP}_{\text {inc }}\right)$ in a certain year is simply calculated by subtracting the number of jobs in the start-ups of the previous 9 years from total employment. Therefore, the incumbent employment is the number of jobs in businesses that are at least 9 years old.

$$
\begin{aligned}
& \mathrm{EMP}_{\text {inc } t=0}=\mathrm{EMP}_{\text {total } t=0}-\mathrm{EMP}_{\text {new } t=0} \\
& \mathrm{EMP}_{\text {inc } t-1}=\mathrm{EMP}_{\text {total } t-1}-\mathrm{EMP}_{\text {new } t-1}
\end{aligned}
$$

In order to sum up to the total employment, both $\mathrm{EMP}_{\text {new }}$ and $\mathrm{EMP}_{\text {inc }}$ are then weighted to calculate their relative contribution to total employment change. Both are calculated as the share of employees in new businesses and incumbent businesses, respectively, over all employees. This allows us to compare the contribution of startups in $\mathrm{EMP}_{\text {new }}$ and $\mathrm{EMP}_{\text {inc }}$ directly. We refer to the work of Fritsch and Noseleit (2013b) for in-depth information regarding all calculations.

$$
\begin{aligned}
\Delta W \_\mathrm{EMP}_{\text {new }} & =\left(\mathrm{EMP}_{\text {new } t=0}-\mathrm{EMP}_{\text {new } t-1}\right) / \mathrm{EMP}_{\text {total } t-1} \\
\Delta W \_\mathrm{EMP}_{\text {inc }} & =\left(\mathrm{EMP}_{\text {inc } t=0}-\mathrm{EMP}_{\text {inc } t-1}\right) / \mathrm{EMP}_{\text {total } t-1}
\end{aligned}
$$

We run three separate regressions for the three dependent variables for the following regional contexts: declining, stable and growing regions. The main explanatory variable consists of the start-up rates in the region, of which we use nine time lags. This is however somewhat problematic, as in reality regional start-up rates are heavily correlated over time (Andersson and Koster 2011) causing problems of multicollinearity. To avoid these problems we use polynomial distributed lags (PDL), also known as the Almon lag method, using a third-order polynomial for estimating the lag structure, which turns out to be the best approximation (Fritsch and Noseleit 2013a; Baptista and Preto 2011). Basically this method reduces the effect of multicollinearity by imposing restrictions on the parameters of the start-up rates, which are then placed back in

\footnotetext{
${ }^{2}$ We choose nine time lags, as empirical test results indicated 9 was the optimal number of lags. Previous studies showed the time period varies between 6 and 10 years to identify statistically significant effects of start-ups on employment. We estimated a vector autoregression (VAR) model (Thurik et al. 2008). Based on the VAR we determined the ideal number of lags to include in the regressions. The results of the LR test and the Akaike information criterion indicate 9 lags is optimal.
} 
the original equation (the $\alpha$ in the model-Table 3). We refer to van Stel and Storey (2004), Fritsch and Noseleit (2013a,b) and Van Stel and Suddle (2008) for a similar application of this method using start-up rates and employment growth rates of, respectively British, German and Dutch regions.

\subsubsection{Controls}

Complementing the method used, we include several control variables in the models that are likely to have an impact on regional employment change, to make sure the outcome of the start-rates are as accurate as possible. Table 1 provides an overview of all the variables used, and Table 2 gives some descriptives of the main variables. First,

Table 1 Variables used

Start-ups

Population change

Urbanization

Controls

Agency dummy
Start-up rates with maximum 15 employees in the initial year. Except agriculture, labour market approach (dividing the number of start-ups by the potential labour market (age 15-65) per region)

Population change per year, data from Statistic Netherlands. For further analysis, three categories are used: decline (less than $-1 \%)$; stable $(-1>$ $<1 \%$ ); growth (>1\%), 2 year mean of 1996-2007 to avoid heavy fluctuations and to allow some response time for the dependent variable

Population density - based on address density per square kilometre, from Statistics Netherlands at municipality level (log). Using the average number of addresses $/ \mathrm{km}^{2}$ within a radius of $1 \mathrm{~km}$ from each individual address, address density uses the concentration of human activities such as living, working and utilizing amenities as indicators of urbanization - the lower the concentration of these activities, the lower the level of urbanization (Haartsen 2002)

Commuting is measured in absolute numbers of incoming commuters in 1998, 2000, 2004 and 2005 due to data availability. Based on these years a trend line was determined and applied to the remaining years

Age distribution is measured by annual numbers of inhabitants in two categories "Under_15" and "Over_65". Data from Statistics Netherlands

Share of higher educated inhabitants relative to the active workforce (log), annual data of 1997-2007 due to data availability. Sixty-one small municipalities were excluded from the source dataset for privacy reasons. These municipalities are estimated based on the share of higher educated in the COROP region. Data from the EBB (Enquete Beroepsbevolking) executed by Statistics Netherlands

Share of immigrants, annually per inhabitant per municipality. Statistics Netherlands, municipality level

The annual share of low income households between 1997 and 2009 is used as a proxy for level of income per municipality. Low income households are in the 2nd, 3rd and 4th decile, the upper limit was 17.100 euro in 1997 and 23.700 in 2009

Annual sector shares, measured in share of jobs per municipality, based on the LISA dataset. We used eight sectors based on a classification provided by Van Oort (2002): resource based activities, production (reference category), physical infrastructure, distribution, consumer-based activities, well-being, information activities, information infrastructure

The 20 LISA regions were included as dummy variables 
Table 2 Descriptives of main variables

\begin{tabular}{lccccl}
\hline Variables & Mean & SD & Min. & \multicolumn{1}{l}{ Max. } & \multicolumn{1}{l}{ Observations } \\
\hline Start-up rate & 2.43 & 1.41 & 0 & 16.23 & $N=5852 / n=418 / T=14$ \\
EMP $_{\text {total }}$ & 1.92 & 4.85 & -47.42 & 101.17 & $N=5852 / n=418 / T=14$ \\
EMP $_{\text {new }}$ & 1.46 & 0.84 & 0 & 6.75 & $N=2090 / n=418 / T=5$ \\
EMP $_{\text {inc }}$ & -0.06 & 3.24 & -18.46 & 25.32 & $N=2090 / n=418 / T=5$ \\
Population change & 0.38 & 1.12 & -11.51 & 13.73 & $N=5852 / n=418 / T=14$ \\
\hline
\end{tabular}

urbanization is used to control for several regional characteristics such as housing prices, qualified labour, local demand, and knowledge (Mueller et al. 2008; Van Stel and Suddle 2008; Audretsch and Fritsch 2002). At this point, we would like to note that population decline is not solely a rural phenomenon in the Netherlands. Table A2 in the ESM appendix illustrates this. Including urbanization as an independent variable does not interfere with the main variable of interest; population decline. Second, we use the absolute number of incoming commuters to account for spatial interactions between municipalities. The municipal level is fairly small, and generally smaller than the labour market area. In order to control for potential influences at higher spatial scales, we account for commuting patterns. Commuting patterns provide an indication to what extent a municipality depends on other municipalities for its economic development and they reflect the core and hinterland of the functional urban areas (OECD 2014). In addition, we lag certain variables using a spatial weights matrix based on first-order contiguity. ${ }^{3}$ These variables are prefaced by $W_{-}$.

We control for the changing demographic composition by including the developments in youngsters and adults aged 65 or older as it is observed that an ageing population can have a negative impact on entrepreneurial activity (Storey 1994; Binet and Facchini 2013). To control for the effect of regional human capital on employment growth, we include the share the higher educated people. The share of immigrants, both international and interregional, is also included as recent studies have clearly illustrated the important impact of immigrants on economic development (Lisenkova et al. 2013). We also control for income developments. A change in regional income entails a change in potential regional demand, which prompts higher levels of employment from new business creation (Audretsch and Fritsch 1994; Knoben et al. 2011). Finally we control for sector structure (Baptista et al. 2005; Van Stel and Storey 2004) and to cope with the data limitation of systematic differences across the collection agencies, we use a dummy variable for the 20 agencies. The model can be expressed by the following equation:

$$
\begin{aligned}
\Delta \mathrm{EMP}_{\mathrm{r}}= & f\left(\mathrm{NFF}_{\mathrm{LAG} t 0-t-9}+\mathrm{POP}_{\mathrm{c}}+W_{\mathrm{POPC}}+\mathrm{URB}+W_{\mathrm{URB}}\right. \\
& +\mathrm{COMMUTE}+\mathrm{AGE}+W_{\mathrm{AGE}}+\mathrm{HIGH}_{\mathrm{EDU}}+W_{\mathrm{EDU}}+\mathrm{IMM} \\
& \left.+\mathrm{INCOME}+W_{\mathrm{INCOME}}+\mathrm{SEC}+\mathrm{LISA}+\varepsilon\right)
\end{aligned}
$$

\footnotetext{
3 We experimented with alternative set-ups of the weight matrix based on distance. The main results were robust to these changes and the influence of the lagged variables themselves did not change importantly either. For the sake of parsimony, we only show the results based on the contiguity matrix.
} 


\section{Results}

Before we determine the employment effects of new business creation for declining and growing regions separately, we first assess the overall impact of start-ups on employment change in new and young firms, incumbent firms as well as the total employment effect. We use these models as a baseline for the remaining results. The results are shown in Table 3 and visualized in Fig. 3.

Using the PDL we found highly significant results for nearly all time-lagged start-up rates. The exception is $t-5$ with employment change in incumbent firms as the dependent variable. This is the precise turning point from negative impact in stage 2 towards positive impact in stage 3; the results are thus near zero. The control variables are most relevant for the employment change in new and young firms. We find a negative effect of commuting on employment change in new and young firms which suggests that people find employment elsewhere rather than in local newly started businesses. The effect of commuting behaviour, however, is rather small and insignificant for total employment change and employment change in incumbent firms. Possibly, urbanization already accounts for the main commuting effect. Higher education shows the expected positive sign, but is statistically insignificant. Age distribution is also mainly insignificant, but there is an interesting positive result for the effect of ageing on employment growth in incumbent firms. This could partly reflect the relative conservative preferences of the elderly to buy their goods and services from the older local businesses (Lunsford and Burnett 1992), and it could partly reflect a higher demand for existing care facilities. Population change shows the expected positive sign and has a negative impact in the neighbouring region. This suggests some competition effects between municipalities as it indicates that if the population grows in one municipality, employment in the surrounding region declines. It may also show a functional difference, with some municipalities focussing on work and others on residential functions. For the industry shares, most impact was seen for 'distribution' and 'consumer-based activities' for all three dependent variables.

Visualizing the outcomes described in the above results in Fig. $3 .{ }^{4}$ On the vertical axis of Fig. 3, we see the impact of new firms on employment change in the different establishment groups (new firms, incumbent firms and total) and on the horizontal axis the timing of the effects (in years). The figure shows the high positive effect in the year of start-up, immediately followed by a steep decline in the following years, turning positive from approximately time lag 6 . The $s$-curve is precisely what we would expect based on the work done by Fritsch and Noseleit in Germany or Van Stel in the Netherlands. The employment change in incumbent firms, the indirect effect, determines the total employment change; the patterns are very similar. The pattern of the impact on new and young firms also confirms previous research; a positive effect at first and relatively flat from $t=2$ onwards. There are, however, also some notable differences with the previous studies. Summing the coefficients of start-ups on employment change over the period of analysis reveals that there is only a $0.14 \%$ employment growth that is due to new business creation over a period of 10 years

\footnotetext{
4 Please note all full tables are readily available from the corresponding author but are not all included due to space restrictions. Control variables and $R^{2}$ are very consistent, compared to the results in Table 3 .
} 
Table 3 Estimated PDL models

\begin{tabular}{|c|c|c|c|}
\hline & Total employment & Incumbents & New and young \\
\hline \multicolumn{4}{|l|}{ Start-up rate } \\
\hline$t=0$ & $0.88 * * *$ & $0.42 * * *$ & $0.46^{* * *}$ \\
\hline$t=1$ & $0.06 * * *$ & $-0.10^{* * *}$ & $0.16^{* * *}$ \\
\hline$t=2$ & $-0.34 * * *$ & $-0.33 * * *$ & $-0.02 * * *$ \\
\hline$t=3$ & $-0.43^{* * *}$ & $-0.33 * * *$ & $-0.09 * * *$ \\
\hline$t=4$ & $-0.30 * * *$ & $-0.20 * * *$ & $-0.10 * * *$ \\
\hline$t=5$ & $-0.07 * * *$ & -0.01 & $-0.06^{* * *}$ \\
\hline$t=6$ & $0.16 * * *$ & $0.17 * * *$ & $-0.01 * * *$ \\
\hline$t=7$ & $0.27 * * *$ & $0.25 * * *$ & $0.03 * * *$ \\
\hline$t=8$ & $0.17 * * *$ & $0.15^{* * * *}$ & $0.02 * * *$ \\
\hline$t=9$ & $-0.26^{* * *}$ & $-0.21 * * *$ & $-0.05 * * *$ \\
\hline$C$ & 2.01 & $2.36^{*}$ & $-0.34 *$ \\
\hline Population change & $0.34 * *$ & $0.29 * *$ & $0.05 * *$ \\
\hline W_Population Change & $-1.81 * * *$ & $-1.71 * * *$ & -0.10 \\
\hline Urbanization (log) & $-0.49 * * *$ & $-0.30 * *$ & $-0.19 * * *$ \\
\hline W_Urbanization & -0.02 & -0.04 & 0.02 \\
\hline Commute & -0.00 & -0.00 & $-0.00 * * *$ \\
\hline Higher educated (log) & 0.33 & 0.26 & 0.06 \\
\hline$W_{-}$Higher Educated & 0.02 & 0.03 & -0.01 \\
\hline Immigrants & -0.01 & -0.00 & $-0.01 * *$ \\
\hline Income (low) & 0.02 & 0.01 & $0.02 * * *$ \\
\hline W_Income & 0.02 & -0.00 & $0.03 * *$ \\
\hline Youngsters & 0.02 & 2.36 & -0.01 \\
\hline Elderly & -0.09 & $0.29 *$ & 0.01 \\
\hline Industry shares & Yes & Yes & Yes \\
\hline Agency dummies & Yes & Yes & Yes \\
\hline$\alpha 1$ & $-0.30 * * *$ & $-0.92 * * *$ & $-0.10 * * *$ \\
\hline$\alpha 2$ & $0.20 * * *$ & $-0.20 * * *$ & $0.02 * * *$ \\
\hline$\alpha 3$ & $0.05^{* * *} *$ & $0.18 * * *$ & $0.02 * * *$ \\
\hline$\alpha 4$ & $-0.02 * * *$ & $0.03 * * *$ & $-0.00 * * *$ \\
\hline$R^{2}$ & 0.16 & 0.14 & 0.70 \\
\hline Log likelihood & -5301.68 & -5263.36 & -1336.02 \\
\hline$F$-statistic & 9.44 & 8.00 & 114.56 \\
\hline Prob. (F-statistic) & 0.00 & 0.00 & 0.00 \\
\hline$N$ & 2090 & 2090 & 2090 \\
\hline
\end{tabular}

* Significant at the $10 \%$ level

** Significant at the $5 \%$ level

*** Significant at the $1 \%$ level

(Table 4). The sum of the coefficients in new firms is much larger than the sum of the indirect effect in incumbent firms. Employment change in incumbent firms, as a result of new business creation, sums up to a negative overall impact. The total 


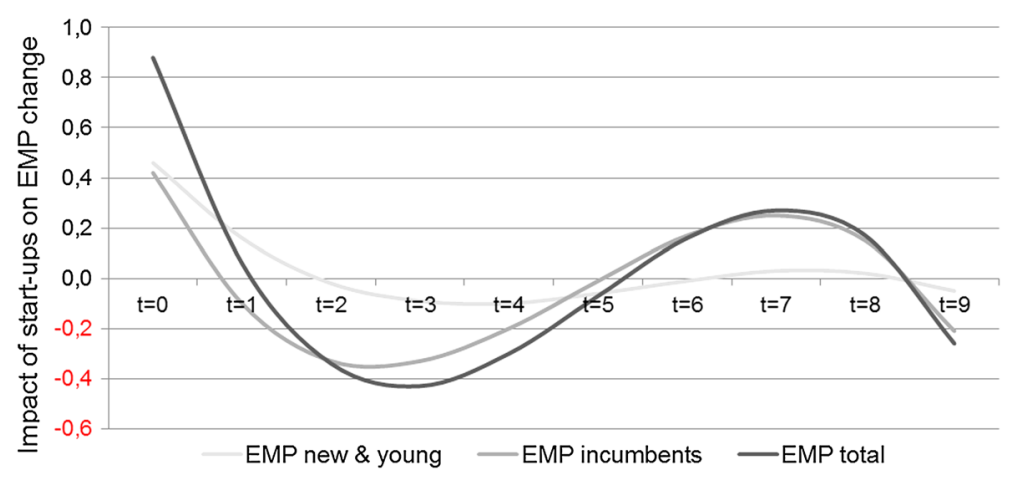

Fig. 3 Impact of start-ups, split up in total employment, new and young firms and incumbents

Table 4 Sum of lags, impact start-up rate on employment growth

\begin{tabular}{lrccccrr}
\hline Sum of lags & All & Decline & Stable & Growth & Rural & Interm. & Urban \\
\hline New and Young & 0.34 & 0.32 & 0.40 & 0.36 & 0.57 & 0.42 & 0.46 \\
Incumbents & -0.19 & -0.03 & -0.71 & -0.26 & -0.54 & 0.12 & -0.39 \\
Tot emp. & 0.14 & 0.28 & -0.31 & 0.10 & 0.03 & 0.54 & 0.07 \\
\hline
\end{tabular}

employment growth is mainly due to the direct effect of employment in new firms. This contradicts the above mentioned papers, although Mueller et al. (2008) also found negative total effects of new business creation for what they call the 'wrong type' of entrepreneurship. More recently, the OECD published a report supporting our finding: young firms contribute more to aggregate employment growth compared to incumbent firms (Criscuolo et al. 2014). It confirms our assumption of heterogeneity within firms: some contribute and some do not.

We now explore whether these results vary per type of region. We differentiate the three dependent variables for regions undergoing population decline and then stable regions and growing regions. Note the sum of all coefficients of the period studied are already included in Table 4.

\subsection{Start-ups and the degree of population change}

Figure 4 shows the impact of new business creation in regions with different dynamics in demographics. The top graph shows the impact of start-ups on total employment change, the effects within new and young firms is shown in the middle and the bottom graph visualized the effects within incumbent firms. At first glance, we notice that the pattern in declining regions is much flatter, with less negative impact and the positive effects are not as high as they are in stable and growing regions. Again though, looking at the sum of the lags, it becomes clear that new firms in declining regions do have a significant impact on employment change. Even more so, the total effect is higher than seen in growing and stable regions. Stable regions do not seem to be able to 


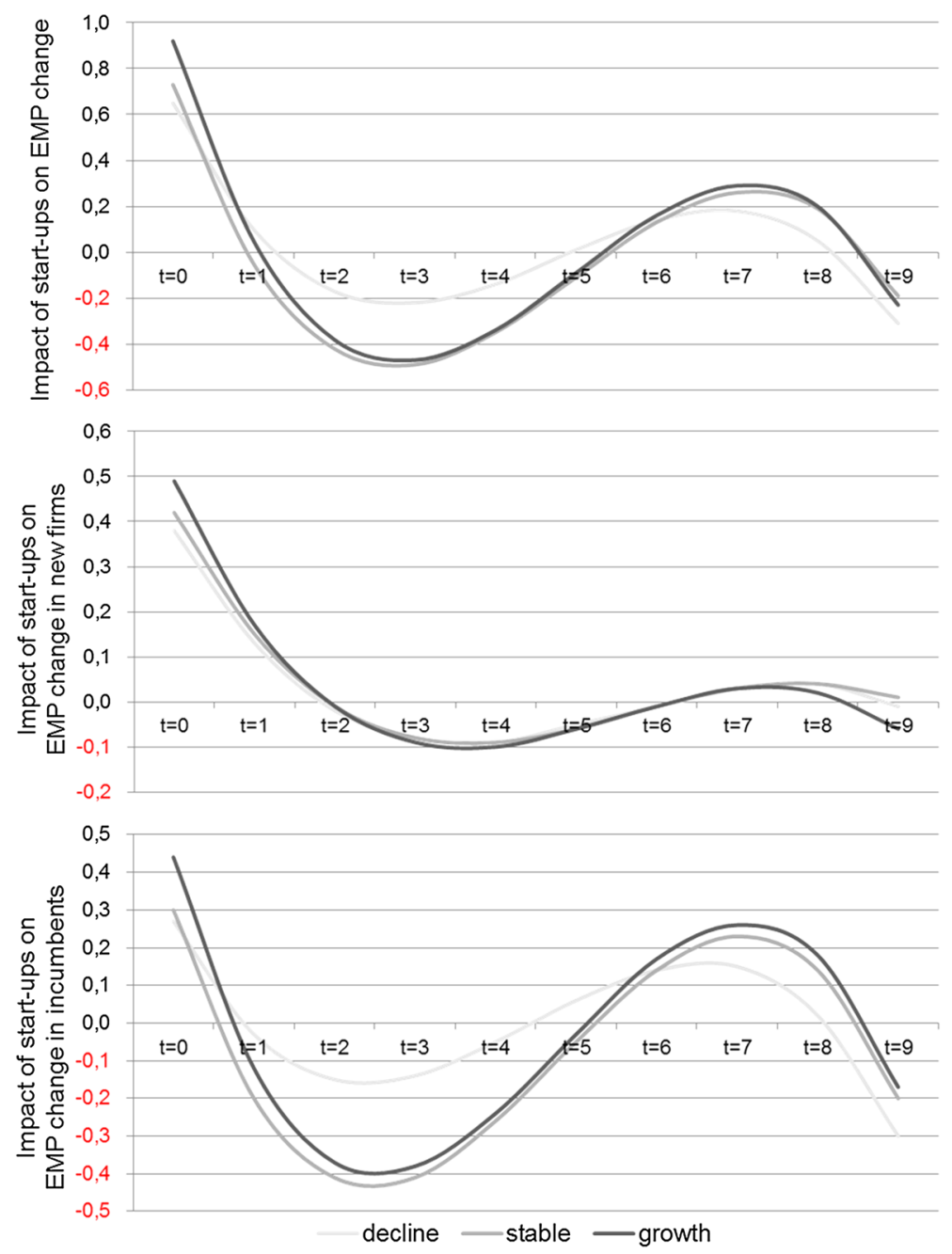

Fig. 4 Impact of start-ups on EMP change, split up in declining, stable and growing regions

compensate for the strong displacement effects in time lag 2 till 5 and add up to a negative overall effect.

The results so far indicate that entrepreneurs in declining regions do have a significant impact on employment growth, both in the long and short term. The top graph shows that the results are consistent with the first hypothesis that new businesses in regions facing population decline are likely to have a short-term effect on employment growth primarily. This could mean the mechanisms described in the theory are at play, either spatial sorting in the type of business started or it is the result of the context in which the new businesses start. There could be a lack of competition, which should indeed result in relatively high immediate effect due to new capacity but limited displacement and induced effects. It is important to note that with our data, we 
measure the nett effects within these regions. We cannot test the relative contributions of mechanisms underlying the results.

The middle graph indicates very little variation amongst declining, stable and growing regions concerning the direct impact within new and young firms. The sum of all lags is nearly the same, with declining regions performing just under stable regions by $0.08 \%$ and growth regions by only $0.04 \%$ with regard to the direct effects. The assumptions based on Reilly's law as described in the theory section are not visible in our results. Even though we can safely state that the consumer base will become smaller in population declining regions, we find no evidence that the change is more than proportional.

The results show no substantial differences between the types of region for jobs created in the new and young firms, but they do show a clear distinction in the indirect effects (Fig. 4, bottom graph), further underlying the first hypothesis. The pattern for declining regions is rather flat and similar to the pattern for total employment, whereas growing regions, but in particular stable regions, show fairly steep highs and lows. This indicates that established firms in declining regions are impacted less by the newcomers, which could indeed be explained partially by relative low quality and growth ambition due to push motivation and selection processes.

Browsing back to Table 4 we find an unexpected result for the incumbent firms. The total impact, the sum of all lags, is negative in nearly all cases. The positive impact in the first and third stages does not seem to compensate for the negative displacement effects in the second stage, which are most pronounced in stable regions. The strong displacement effects can be explained by intense competition and selection. Apparently, this does not translate into supply side effects that are great enough to ensure overall growth.

Answering the second hypothesis is less straightforward. The direct employment effects were lower in declining regions, but not by much. The displacement effects and supply side effects were indeed stronger present in stable and growing regions and the indirect effects in declining regions are negative, but so are they in stable and growing regions. In declining regions, they were actually the least negative, causing the overall employment effects to be the largest in declining regions. The latter means we should reject the second hypothesis as it is concerned with the total employment effect, but when we narrow our focus on the long-term effects, the graphs in Fig. 4 clearly show a lower line-leaving the answer open to interpretation.

\section{Conclusion}

The main goal of this paper was to disentangle the impact of new business creation on regional employment growth in different regional contexts, and in particular to compare declining regions with growing regions. A prime finding of the study is that start-ups do have a positive and significant impact on employment change in municipalities facing population decline, despite the adverse circumstances of population shrinkage. This suggests that population decline in itself is not a reason for concern regarding employment growth induced by start-ups. 
A second main finding is that the indirect employment effect of start-ups-that is the responses of the incumbent firms to the challenges set by new businesses-are limited in regions facing population decline. This suggests that the incumbent firms are resistant to the challenges set by the new business, possibly because the new firms are not raising the bar in terms of innovation. As a result, displacement effects induced by new businesses are limited which has a positive effect on employment in the medium term. At the down side, this may signify a lack of creative destructive processes, which may jeopardize the economic viability of such a region in the long run.

The empirical findings in the study are in line with the conceptual ideas on how a declining population influences the employment effects of business formation through, for example, limited growth aspirations of the founders or decreasing access to the market as well as suitable employees. The study, however, does not address these mechanisms directly, and the findings should therefore be seen as stylized facts on how context, specifically a declining population, is important in the regional economic effects of entrepreneurship. A useful follow-up on this study would be to address these mechanisms directly. One extension would be to incorporate information on the characteristics of the founders in order to assess to which extent geographical selection processes of the founders are pertinent to the findings found here. Also, the changing composition of the demand market will require a changed supply of goods and services. Industry dynamics in relation to population decline is thus a useful avenue to further clarify the mechanisms driving the employment effect of business creation. As a final example, it may be worthwhile to directly assess the competitive forces that incumbents experience in different regional contexts.

Even though this study does not uncover the precise mechanisms that govern the employment effects of new business creation, it does reiterate the importance of the regional context in economic development. Specifically, it shows that the patterns in employment generation are indeed different in declining regions. Importantly, however, the overall employment effect of entrepreneurship was found to be positive. This is an important finding in the sense that it suggests local governments to keep on fostering new business creation, also in more adverse economic contexts. This nuances more critical views by, for example, Shane (2009) who argues that by encouraging more people to start businesses, economic growth will not be enhanced nor will it create a lot of jobs based on the basic assumption that the vast majority of people starting a business are not generating additional jobs and wealth. His reasoning, however, only refers to the jobs created within new businesses. We find that even though entrepreneurship in population declining regions generates fewer economic benefits compared to other regions in the short term, the effects are positive. It is important to note that we have focused on slow population decline, which is different from a rapid decline. Slow decline provides the opportunity for people and policy makers to adjust to the new situation, to plan for it, whereas rapid decline will require a different, more intensive approach. Given that the changes are slow, market mechanisms will be able to deal with some of the new developments. In many occasions, people will be able to adapt to the new situation. Still, in other areas, there will be a need for stronger interventions, in particularly if the labour market (or housing market) is no longer fully functioning. 
Open Access This article is distributed under the terms of the Creative Commons Attribution 4.0 International License (http://creativecommons.org/licenses/by/4.0/), which permits unrestricted use, distribution, and reproduction in any medium, provided you give appropriate credit to the original author(s) and the source, provide a link to the Creative Commons license, and indicate if changes were made.

\section{References}

Acs Z, Audretsch D (1990) Innovation and small firms. MIT Press, Cambridge

Acs Z, Audretsch D (2003) Innovation and technology change. In: Acs ZJ, Audretsch DB (eds) Handbook of entrepreneurship researcher. Kluwer, Dordrecht, pp 55-79

Acs Z, Varga A (2005) Entrepreneurship, agglomeration and technological change. Small Bus Econ 24(3):323-334

Alhabeeb MJ (2014) Entrepreneurial finance: fundamentals of financial planning and management for small business. Wiley, New York

Andersson M, Koster S (2011) Sources of persistence in regional start-up rates-evidence from Sweden. J Econ Geog 11(1):179-201

Andersson M, Noseleit F (2011) Startups and employment dynamics within and across sectors. Small Bus Econ 36(4):461-483

Armington C, Acs Z (2002) The determinants of regional variation in new firm formation. Reg Stud 36(1):33-45

Audretsch D, Fritsch M (1994) The geography of firm births in Germany. Reg Stud 28(4):359-365. http:// www.tandf.co.uk/journals/titles/00343404.asp

Audretsch D, Fritsch M (2002) Growth regimes over time and space. Reg Stud 36(2):113-124

Audretsch D, Thurik A (2000) Capitalism and democracy in the 21st century: from the managed to the entrepreneurial economy. J Evol Econ 10(1):17-34

Baptista R, van Stel A, Thurik A (2005) Entrepreneurship, industrial restructuring and unemployment in Portugal. In: Portugal E, Santarelli E (eds) Entrepreneurship, growth, and innovation: the dynamics of firms and industries. International studies in entrepreneurship. Springer, Berlin

Baptista R, Preto M (2011) New firm formation and employment growth: regional and business dynamics. Small Bus Econ 36(4):419-442. doi:10.1007/s11187-009-9254-y

Barca F (2009) An agenda for a reformed cohesion policy: a place-based approach to meeting European Union challenges and expectations. European Commission, Brussels

Baumgartner D, Schulz T, Seidl I (2013) Quantifying entrepreneurship and its impact on local economic performance: a spatial assessment in rural Switzerland. Entrep Reg Dev 25(3-4):222-250

Binet M, Facchini F (2013) Determinants of entrepreneurship in French regions: the role of spatial heterogeneity. WP2013-12. Center for Research in Economics and Management. University of Rennes 1, University of Caen and CNRS

Bönte W, Falck O, Heblich S (2009) The impact of regional age structure on entrepreneurship. Econ Geogr 85(3):269-287

Bosma N, van Stel A, Suddle K (2008) The geography of new firm formation: evidence from independent start-ups and new subsidiaries in the Netherlands. Int Entrep Manag J 4(2):129-146. http://www. springerlink.com/content/1554-7191

Brooksbank DJ, Jones-Evans D, Kwong C, Thompson P (2008) Standing on the shoulders of giants: further evidence on the relationship between unemployment and entrepreneurship. NEO working paper series, paper no. 17. National Entrepreneurship Observatory, Cardiff, Wales

Carrasco R (1999) Transitions to and from self-employment in Spain: an empirical analysis. Oxf Bull Econ Stat 61(3):315-341

Carree MA, Thurik AR (2003) The impact of entrepreneurship on economic growth. In: Audretsch DB, Acs ZJ (eds) Handbook of entrepreneurship research. Kluwer, Dordrecht

Carree MA, Thurik AR (2008) The lag structure of the impact of business ownership on economic performance in OECD countries. Small Bus Econ 30:101-110

Chasco C, Vicéns J (1998) Spatial interaction models applied to the design of retail trade areas. In: 38th congress of the European Regional Science Association, vol 28

Coleman D, Rowthorn R (2011) Who's afraid of population decline? A critical examination of its consequences. Popul Dev Rev 37(s1):217-248. doi:10.1111/j.1728-4457.2011.00385.x 
Criscuolo C, Gal PN, Menon C (2014) The dynamics of employment growth: new evidence from 18 countries. OECD science, technology and industry policy papers, no. 14. OECD, Paris. doi:10.1787/ 5jz417hj6hg6-en

Dahl MS, Sorenson O (2012) Home sweet home: entrepreneurs' location choices and the performance of their ventures. Manag Sci 58(6):1059-1071

Davidsson P (1991) Continued entrepreneurship: ability, need, and opportunity as determinants of small firm growth. J Bus Ventur 6(6):405-429

Delfmann H, Koster S, Mccann P, van Dijk J (2014) Population change and new firm formation in urban and rural regions. Reg Stud 48(6):1034-1050. doi:10.1080/00343404.2013.867430

Eliasson K, Westlund H (2013) Attributes influencing self-employment propensity in urban and rural Sweden. Ann Reg Sci 50(2):479-514

European Commission (2010) Investing in Europe's future: fifth report on economic, social and territorial cohesion. European Commission, Brussels

Fésüs G, Rillaers A, Poelman H, Gáková Z (2008) Regions 2020. Demographic challenges for European regions. Background document to commission staff working document Sec (2008), 2868 final regions 2020, an assessment of future challenges for EU regions. European Commission, Brussels

Fritsch M (2008) How does new business formation affect regional development? Introduction to the special issue. Small Bus Econ 30(1):1-14. doi:10.1007/s11187-007-9057-y

Fritsch M (2015) Methods of analyzing the relationship between new business formation and regional development. In: Karlsson C, Andersson M, Norman T (eds) Handbook of research methods and applications in economic geography. Edward Elgar, Cheltenham, pp 303-320

Fritsch M, Mueller P (2004) The effects of new business formation on regional development over time. Reg Stud 38:961-975

Fritsch M, Noseleit F (2009) Start-ups, long- and short-term survivors and their effect on regional employment growth. Jena economic research papers, no. 81. Friedrich Schiller University and Max Planck Institute of Economics, Jena

Fritsch M, Noseleit F (2013a) Indirect employment effects of new business formation across regions: the role of local market conditions. Pap Reg Sci 92:361-382. doi:10.1111/j.1435-5957.2012.00475.x

Fritsch M, Noseleit F (2013b) Investigating the anatomy of the employment effect of new business formation. Camb J Econ 37(2):349-377

Fritsch M, Noseleit F, Schindele Y (2008) Direct and indirect effects of new businesses on regional employment—an empirical analysis. Jena economic research papers, no. 74. Friedrich Schiller University and Max Planck Institute of Economics, Jena

Gáková Z, Dijkstra L (2010) Does population decline lead to economic decline in EU rural regions? Regional focus. Eurpean Union, regional policy, no. 01/2010. EU Regional Policy, Brussel

Gilad B, Levine P (1986) A behavioral model of entrepreneurial supply. J Small Bus Manag 24(4):45-54

Glaeser EL, Kallal HD, Scheinkman JA, Shleifer A (1992) Growth in cities. J Polit Econ 100(6):1126-1152

Glaeser EL, Scheinkman J, Shleifer A (1995) Economic growth in a cross-section of cities. J Monet Econ 36(1):117-143. doi:10.1016/0304-3932(95)01206-2

Haartsen T (2002) Platteland: boerenland, natuurterrein of beleidsveld? Een onderzoek naar veranderingen in functies, eigendom en representaties van het Nederlandse platteland. Nederlandse Geografische Studies, Utrecht, no. 309

Haartsen T, Venhorst V (2010) Planning for decline: anticipating on population decline in the Netherlands. Tijdschr Soc Econom Geogr 101(2):218-228

Hartog C, Parker S, van Stel A, Thurik R (2010) The two-way relationship between entrepreneurship and economic performance. Scientific AnLysis of Entrepreneurship and SMEs (SCALES), Zoetermeer

Head K, Mayer T (2006) Regional wage and employment responses to market potential in the EU. Reg Sci Urban Econ 36(5):573-594

Hoogstra G, van Dijk J (2004) Explaining firm employment growth: does location matter? Small Bus Econ 22:179-192

Knoben J, Ponds R, van Oort F (2011) Employment from new firm formation in the Netherlands: agglomeration economies and the knowledge spillover theory of entrepreneurship. Entrep Reg Dev Int J 23(3-4):135-157. doi:10.1080/08985620903183736

Koster S (2011) Individual foundings and organizational foundings: their effect on employment growth in the Netherlands. Small Bus Econ 36(4):485-501

Koster S, van Stel A (2014) The relationship between start-ups, market mobility and employment growth: an empirical analysis for Dutch regions. Pap Reg Sci 93(1):203-217 
Li H, Cheng S, Haynes KE (2011) The employment effects of new business formation: a regional perspective. Econ Dev Q 25(3):282-292

Limburg P (2011) Krimp en economische groei gaan prima samen. Nieuwsbrief Parkstad Limburg, Speciale editie voor Kamerleden, Krimp

Lisenkova K, Méretta M, Sanchez-Martinez M (2013) The long-term economic impacts of reducing migration: the case of the UK migration policy. Discussion paper no. 420. National Institute of Economic and Social Research, London

Little JS, Triest RK (2001) Seismic shifts: the economic impact of demographic change. An overview. In: Conference series-Federal Reserve Bank of Boston, vol 46. Federal Reserve Bank of Boston

Lunsford DA, Burnett MS (1992) Marketing product innovations to the elderly: understanding the barriers to adoption. J Consum Mark 9(4):53-62

Meccheri N, Pelloni G (2006) Rural entrepreneurs and institutional assistance: an empirical study from mountainous Italy. Entrep Reg Dev 18(5):371-392

Mueller P, van Stel A, Storey DJ (2008) The effects of new firm formation on regional development over time: the case of Great Britain. Small Bus Econ 30(1):59-71. doi:10.1007/s11187-007-9056-Z

OECD (2004) Local economic and employment development. Entrepreneurship, a catalyst for urban regeneration, chap 2: entrepreneurship financing in distressed urban areas: european experience. Rudy Aernoudt, Paris

OECD (2008) OECD rural policy reviews: Netherlands, Paris and Washington, DC. OECD, Paris

OECD (2011) OECD regional outlook 2011, building resilient regions for stronger economies. OECD, Paris

OECD (2013) Rural-urban partnerships: an integrated approach to economic development. OECD, Paris

OECD (2014) OECD territorial reviews: Netherlands 2014. OECD, Paris

Reher DS (2007) Towards long-term population decline: a discussion of relevant issues. Eur J Popul Rev Eur Démogr 23(2):189-207. doi:10.1007/s10680-007-9120-z

Reilly WJ (1931) The law of retail gravitation. WJ Reilly, New York

Reynolds P, Bygrave WD, Autio E, Cox LW, Hay M (2002) Global entrepreneurship monitor: 2002 executive report. Ewing Marion Kauffman Foundation, London

Schneider L, Eichler S (2007) Ageing in East Germany: remarkable reduction of entrepreneurship. Wirtsch Wandel 13(4):102-109

SER (2011) Bevolkingskrimp benoemen en benutten. Commissie Ruimtelijke Inrichting en Bereikbaarheid no. 3, The Hague

Shane S (2009) Why encouraging more people to become entrepreneurs is bad public policy. Small Bus Econ 33(2):141-149. doi:10.1007/s11187-009-9215-5

Shearmur R, Polèse M (2007) Do local factors explain local employment growth? Evidence from Canada, 1971-2001. Reg Stud 41(4):453-471

Skuras D, Meccheri N, Moreira MB, Rosell J, Stathopoulou S (2005) Entrepreneurial human capital accumulation and the growth of rural businesses: a four-country survey in mountainous and lagging areas of the European union. J Rural Stud 21(1):67-79

Stam E (2009) Entrepreneurship, evolution and geography. Pap Evol Econ Geogr 9:1-23

Stam E (2010) Growth beyond Gibrat: firm growth processes and strategies. Small Bus Econ 35(2):129-135

Sternberg R (2011) Regional determinants of entrepreneurial activities-theories and empirical evidence. In: Fritsch M (ed) Handbook of research on entrepreneurship and regional development. National and Regional Perspectives, Cheltenham, pp 33-57

Sternberg R, Bergman H (2003) Global entrepreneurship monitor: Länderbericht Deutschland 2002. Köln Storey D (1994) Understanding the small business sector. Routledge, London

Thurik AR, Carree MA, Van Stel A, Audretsch DB (2008) Does self-employment reduce unemployment? J Bus Ventur 23(6):673-686

Van Dijk J, Pellenbarg PH (2000) Firm relocation decisions in The Netherlands: an ordered logit approach. Pap Reg Sci 79(2):191-219

Van Oort FG (2002) Agglomeration, economic growth and innovation: spatial analysis of growth and R\&D externalities in the Netherlands. Erasmus University, Rotterdam

Van Stel A, Storey D (2004) The link between firm births and job creation: is there a upas tree effect? Reg Stud 38(8):893-909

Van Stel A, Suddle K (2008) The impact of new firm formation on regional development in the Netherlands. Small Bus Econ 30(1):31-47. http://www.springerlink.com/link.asp?id=100338

Wennekers S, Thurik R (1999) Linking entrepreneurship and economic growth. Small Bus Econ 13:27-55 
Williams N, Williams CC (2012) Beyond necessity versus opportunity entrepreneurship: some lessons from English deprived urban neighbourhoods. Int Entrep Manag J 201:1-18

Willis DB, Boys KA, Hughs DW, Swindall DC (2012) Evaluating the determinants of self-employed income across regional economies: a case-study of the US Southeast. In: 2012 annual meeting, August 12-14, Seattle, WA, USA (no. 124912). Agricultural and Applied Economics Association 